\title{
Disseminated superficial actinic porokeratosis
}

INSERM

\section{Source}

INSERM. (1999). Orphanet: an online rare disease and orphan drug data base.

Disseminated superficial actinic porokeratosis. ORPHA:79152

Disseminated superficial actinic porokeratosis (DSAP) is the most common form of porokeratosis characterized by the presence of several small annular plaques with a distinctive keratotic rim found most commonly on sun-exposed areas of the skin, particularly the extremities. 